\title{
"Proud to be a Special": A qualitative study exploring the experiences of Special Constables in the UK
}

\begin{tabular}{|r|l|}
\hline Journal: & Safer Communities \\
\hline Manuscript ID & SC-08-2019-0024 \\
\hline Manuscript Type: & Research Paper \\
\hline Keywords: & $\begin{array}{l}\text { Qualitative, Special Constable, Police, Volunteer, Neighbourhood Policing, } \\
\text { Austerity }\end{array}$ \\
\hline \multicolumn{2}{|l}{} \\
\hline
\end{tabular}

\section{SCHOLARONE ${ }^{\text {TM }}$ \\ Manuscripts}

Emerald allows authors to deposit their AAM under the Creative Commons Attribution Non-commercial International Licence 4.0 (CC BY-NC 4.0). To do this, the deposit must clearly state that the AAM is deposited under this licence and that any reuse is allowed in accordance with the terms outlined by the licence. To reuse the AAM for commercial purposes, permission should be sought by contacting permissions@emeraldinsight.com.

For the sake of clarity, commercial usage would be considered as, but not limited to:

- Copying or downloading AAMs for further distribution for a fee;

- Any use of the AAM in conjunction with advertising;

- Any use of the AAM by for promotional purposes by for-profit organisations;

- Any use that would confer monetary reward, commercial gain or commercial exploitation.

Emerald appreciates that some authors may not wish to use the CC BY-NC licence; in this case, you should deposit the AAM and include the copyright line of the published article. Should you have any questions about our licensing policies, please contact permissions@emeraldinsight.com. 


\section{MANUSCRIPT DETAILS}

TITLE: "Proud to be a Special": A qualitative study exploring the experiences of Special Constables in the UK

\section{ABSTRACT:}

The paper aims to understand what motivates members of the public to volunteer within the Special Constabulary and seeks to understand their experiences when engaging in this role.

There is little qualitative research examining the experiences of volunteers and yet such literature is pivotal in supporting positive future engagement of a valuable resource.

Six currently serving Special Constables were interviewed about their role. The semi-structured interviews were transcribed and analysed qualitatively through thematic analysis.

Thematic analysis identified four main themes: 1) Proud to be a Special: active demonstration of pro-social behaviour; 2) Lines of division: recognition of distinction between Special Constables and Regular Police Officers; 3) Levels of training: adverse consequences of inadequate training; and, 4) Mind the gap: impact of financial austerity. The Special Constables recognised their role as a utilitarian resource with both positive and negative impacts on all Police Officers.

The findings highlighted the need for a careful balance between having enough Special Constables to maintain appropriate policing and yet ensuring opportunity for sufficient experience to develop and implement their skills, successful demonstration of which would support more positive working relationships with Regular Police Officers. 


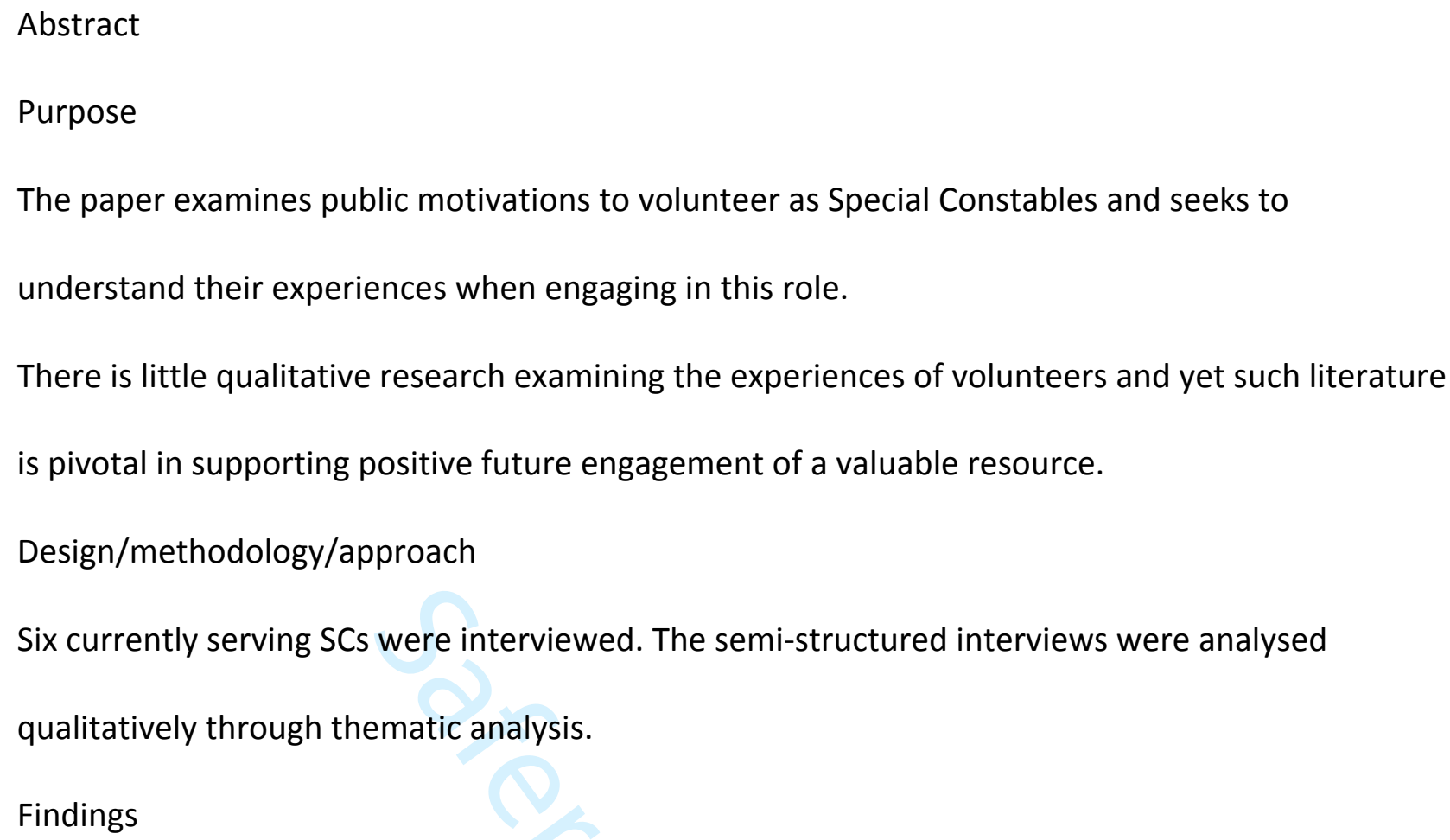


Individuals who are motivated to increase another individual's welfare through volunteering are considered a necessary and welcome asset by many organisations (Hamlyn et al., 2015). Recently, the number of people who volunteer has increased (Prouteau and Boguslawa, 2015), partly in response to changes in political policies, such as severe austerity measures (Casselden, Pickard, Walton and McLeod, 2017). The reasons underlying individual decisions to volunteer include an altruistic motivation to helping others, and associated benefits to the individual (Batson, 2011; Shye, 2010). These benefits can include building skills and obtaining the experience to progress towards a chosen career pathway (Akintola, 2011), or positive affect (Skoglund, 2006). Meer et al. (2013) also noted that some individuals engage in volunteering in order to avoid the detached feeling associated with only contributing financially.

There are two main theoretical explanations for volunteering: Batson's theory of EmpathyAltruism (Batson, 1981), and Social Identity Theory (Tajfel, 1979). Batson states that altruistic acts, originate from the individual being highly empathetic and can enable the volunteer to show empathic concern to another person's situation, and to reduce that person's distress (Batson, 2010; Taylor and Hanna, 2017). Batson (1994) states there are usually one of four motivators for volunteering: volunteering benefits the volunteer personally (Egotism); to increase another's wellbeing (Altruism); to support moral principles (Principalism); and Collectivism, whereby once an individual identifies with a chosen group the aim becomes to increase its success. Collectivism shares similarities with Social Identity Theory (Tajfel, 1979) which explains how people affiliate themselves with groups based on a variety of characteristics to develop a sense of belonging with the 'in-group' (Abrams and Hogg 1988) which may lead to engagement in pro-social behaviours (Gorden, 1988). This engagement can be as a result of development of trust in the organisation and a desire to empathise with the organisation's cause, which in turn increases the group's potential (Batson, 1994). Conversely, however, being, or perceiving oneself to be in an 'out group' can have adverse consequences on self-esteem, anxiety and stress (Meister, 2014). 
The decision to volunteer in a specific area can be based on the individual's own needs and interests, producing a unique person-environment fit (Maki and Snyder, 2017). However, the individual's initial basis for volunteering can stem from the need to fulfil both egoistic and altruistic desires (Fitch, 1987). These desires may result in forming a relationship or identifying with others in a group to achieve a specified goal (Fishback, Henderson and Koo, 2011), particularly where there is a shared understanding of moral convictions (Skitka et al., 2016). For example, the Criminal Justice System in the United Kingdom offers the volunteering role of exoffender peer mentoring. In this role, an ex-offender offers support and advice to inmates in prison. The motivations to be engaged in such a role could be considered as having its roots in the Altruism-Empathy Model (Batson, 1994) as the ex-offender's volunteering is altruistic and in addition may also satisfy an egoistic need for an internal reward for the ex-offender, resulting in feelings of accomplishment (Thomas and Buck, 2010).

Volunteer roles within the Criminal Justice System include mentoring, restorative justice and victim support (Hewson, 2013). Civil unrest during the 1960's saw an increased demand for citizens to assist the Police Force directly (Cook and Scioli, 1974), which led to the development of the Special Constable (SC) voluntary role with the same legal powers as RPOs (College of Policing, 2017a). All SCs volunteer for a minimum of four hours a week, complete 16 days of initial basic training, and exercise police powers including making arrests, stop and search, and executing warrants. In England and Wales in 2018, there were 11,690 serving SCs, working with 122,404 RPOs (Home Office, 2018).

During periods of financial austerity and cuts to public services volunteers represent a much-needed resource facilitating an effective public service (Colley, 2012; Nesbit and Brudney, 2010). Between 2009 and 2014, the government's policy on austerity led to a reduction of 20,000 RPOs (Disney and Simpson, 2017). The SCs save central government over $£ 2$ million per year in revenue that would have been used to fund hours that would be otherwise worked by the RPOs 
(Pepper, 2014). Severe cuts and austerity measures have left many areas of policing vulnerable, especially within the area of Neighborhood Policing (O'Neill, 2015) which is intended to protect local neighbourhoods and communities, to safeguard the vulnerable, and to manage and divert offenders. Policing Vision 2025 (National Police Chiefs' Council, 2018) acknowledged that there was an increased need for more local engagement and connectivity with the public in the form of Neighborhood Policing. Financial cuts during the recent period of austerity have seen the closure of over 600 local police stations nationwide (Pratt, 2019) and the reduction of a local Police presence has been linked to an increase in disruption (Kochel and Weisburd, 2019). Accordingly, the workload of SCs is now being completely moved into Neighbourhood Policing (Higgins, 2018; Strudrick, Jameson and Rowe, 2017), with other SCs assigned to the emergency call Response teams.

Research regarding volunteer police has been primarily focussed on Britain and North America (see Dobrin and Wolf, 2016; Gaines and Kappeler, 2011; Pepper and Wolf, 2015; Wolf, Pepper and Dobrin, 2017) with little attention to developments outside of these locations (for an exception see van Steden and Mehlbaum, 2018). In many countries volunteers are recruited to assist RPOs in conducting patrols, investigations, administrative duties, traffic and community events. Some countries use volunteers in the same role as RPOs whereas others use volunteers to communicate with the RPOs when there are problems arising within the community (Wolf, Pepper and Dobrin, 2017; Dobrin, 2015). The level of training for SCs also varies considerably between countries with the equivalent of approximately of 3-4 weeks in the United Kingdom (College of Policing, 2017a), and a minimum of 319 hours for a similar role in Florida, United States (Wolf, 2015 as cited in Wolf, Pepper and Dobrin, 2017).

The United Kingdom recruits its SCs to perform a role equal to that of a RPOs (College of Policing, 2017b; Bullock and Millie, 2018). Furthermore Jordan (2012) found volunteers in policing helped to strengthen 'Moral Order' in the public sphere. Recruitment of SCs allows for more 
engagement with public and the development of trust, which can benefit the community as a whole (Dobrin, 2017).

There are negative consequences for the SCs through exposure to threatening situations, work-based stress, increased risk of developing related mental illnesses such as depression, anxiety and burnout (Colley, 2012), or adversely affecting decision-making processes (Qi et al., 2018). Another early (and continuing) challenge encountered by SCs was that the RPOs viewed them negatively (Mirrlees-Black and Byron, 1994). High levels of recruitment masked high levels of attrition in the SCs, which challenges the assumption that SCs provide value for money (Whittle, 2014). Volunteer retention was also highlighted by Millie (2016) who found that attrition related to the SCs' views about being under-informed and underused.

Research into SCs is both limited regarding the perspectives of the SCs, or their perceptions of their role (Whittle, 2014). To encourage recruitment, further engagement, and retention is essential as volunteers within the Police Force provide a crucial supportive role within the Criminal Justice System (Pepper and Wolfe, 2015). As the volunteering role of the SC is highly specific and complex, the flexibility of a qualitative approach, utilising semi-structured interviews and then conducting a thematic analysis (Braun and Clarke, 2013; Braun, Clarke and Terry, 2012) was considered the most appropriate approach for this study. The semi-structured interviews allowed an exploration of SCs' perceptions of their volunteering experience. This would assist in the formation of policy and development of voluntary experiences, inform evidence-based practice, and, promote an environment in which the role of a SC is viewed positively, from the perspective of all individuals concerned.

\section{Method}

\section{Design}

Semi structured interviews were conducted with six currently serving SCs to explore their experiences, opinions and perspectives of their volunteering role. A standardised open-ended 
approach (Cresswell, 2013) was used, which could be expanded upon depending on each participant's response. The interview covered areas such as motivation to volunteer, the reasons for undertaking volunteering as a SC, the participant's experiences within that role, and expectations for the future. The questions were designed to encourage in-depth discussion on the participant's experiences; for example 'What made you decide to become a volunteer?' Following transcription, a qualitative thematic analysis was conducted (Braun and Clarke, 2006).

\section{Participants}

Permission to advertise for participants within a county Police Force in the Midlands of the United Kingdom was requested, and granted, by the Chief Inspector of that county. Six SCs participated (four male, and two female), aged between 21 and $31(M=26.83, S D=4.60)$. The participants had been volunteering for the SCs for between six months and four years $(M=19.00, S D=15.38$ months), and all had engaged previously in other volunteering roles (for example, in the National Health Service, working in youth clubs). The interviews, conducted via Skype, had a duration of between 31 and 87 minutes $(M=53.02$ minutes, $S D=24.85)$.

\section{Ethical considerations}

Ethical approval for this study was obtained from [anonymised] University with particular consideration given to maintaining the anonymity of the SCs, and to remove any case identifying details mentioned in the interviews.

\section{Analytic Procedure}

Prior to analysis the interviews were transcribed, and participants were offered the opportunity to edit their own transcript freely; no interviewees made any amendments. The thematic analysis process started with familiarisation of the data, coding to capture both semantic and conceptual reading of the data, the constructing, reviewing and labelling of initial subthemes, and ultimately of overarching themes to provide a coherent and representative account of the information elicited through the interviews (Braun and Clarke, 2006). 


\section{Analysis}

The coded data from the transcribed interviews gave rise to four overarching themes: 'Proud to be a Special', relating to the active demonstration of pro-social behaviour; 'Lines of division', demonstrating recognition of the distinction and division between SCs and the general public, and between SCs and RPOs; 'Levels of training', and associated consequences with a lack of training provision; and 'Mind the gap', with the impact of austerity on the Police Force as a whole, as well as the impact that this has on the volunteers directly.

\section{Theme 1: 'Proud to be a Special'}

Throughout the interviews the SCs expressed a sense of enduring pride in their role. This was expressed clearly:

'I am still as proud as day one putting on a stab vest and going out on shift; that's what keeps me going'.

Pride was also evident in the general public's response to the SCs: 'when some people recognise that you are a volunteer you know they will say 'that's great, what you're doing'... I think the members of the public have a lot more respect for the fact that you're doing it for free'.

\section{Subtheme 1: 'It takes a certain person'}

The role of a SC is a complex and demanding role. Despite the variety of decisions underlying volunteering for this role (Maki and Snyder, 2017) participants expressed their opinion that not all individuals would be willing or capable of fulfilling this demanding role:

'I gave up 88 hours of my time to keep people safe and not everybody would do that'.

Participants defined those who became SCs as sharing similarities in their personalities and approach which led to a communal sharing of moral convictions (Skitka, Bauman and Mullen, 2016) and strong belief in the fundamental principle of 'enforcing the law.' 
'We have a fantastic criminal justice system and some fantastic laws and legislations that are wrote down... We're there to enforce the law, regardless of anything else going around.' The sharing of this collectivist approach (Batson, 1994) amongst the participants appears to have its roots in the SCs sharing of mutual purposes and aims, which are supportive of efficiency, success and motivation (Fishback et al., 2011):

'It's sort of that group mentality where you all got the same sort of values and reasons... for doing what we do.'

\section{Subtheme 2: Awareness of motivation}

According to Batson's (1987) research on pro-social motivation, pro-social behaviours are motivated by one's desire for internal rewards. Many participants discussed the self-gratification and rewarding feeling they achieved through volunteering as a SC, and how being a member of a clearly defined group aligned the individual's personal identity to the group with which they are associated:

'I loved the idea. It's very much like a military organisation in terms of professional but you're also part of a family there... you're part of looking out for each other... work with a great bunch of people and come home'.

The motivation to volunteer, however, was not limited to internal rewards but to how the volunteer would be recognised by others:

'I remember reading an obituary to Jo Cox [Member of Parliament for Batley and Spen]... She had been a community volunteer for like 15 years before becoming an MP. As a role model you look at yourself and think what have I done over the last 12 months?... what would somebody write in my obituary?'

This participant proceeded to discuss feelings of guilt when there had been times in his life without a volunteering role and how volunteering limited aversive feelings (Batson 1987): 


\begin{abstract}
'It's strange, it became so ingrained in me so when people talked about the volunteering they do, I always felt quite guilty that I wasn't making a contribution.'
\end{abstract}

Subtheme 3: Prestige and the future

According to Kent and Swanson (2017), a sense of increased self-esteem, pride and confidence is experienced when being accepted as part of an organisation or group that is considered high-level or prestigious. The participants were passionate about a sense of pride in their roles as SCs and some expressed a desire to continue in their role as a RPO:

'I applied to be a Special and I didn't intend to ever actually become a full-time officer. As it happens I actually fell in love with it after about 6 months. So, I actually now hold a place to train as a Regular.'

\title{
Theme 2: 'Lines of division'
}

Mirrlees-Black and Byron (1994) found a division between RPOs and SCs. This division appears to continue to be an issue with current SCs who remain active, rather than being associated only with those SCs who have left the organisation (Millie, 2016). The SCs demonstrated awareness of lines of division not only in respect of their role in relation to the RPOs, but also in relation to the general public, and in themselves as individuals.

\section{Subtheme 1: 'Them and Us'}

Despite the enthusiasm of participants towards the unique role of SC, there were also challenges faced, and challenges expected, but not experienced. The SCs expressed surprise that 'The public are actually nicer than I had expected them to be'. Even when circumstances were less positive, and the SC was required to act this did not detract from a positive relationship with the public: 'I don't think negatively of the people you are arresting... hasn't made me want to be put off by it because l expected it'.

However, concern was raised by the SCs as to the public expectations and understanding of their role: 
'You know when you are out on shift people see you as a police officer, you are in uniform, you don't look any different to RPOs... that member of the public doesn't know if you've been in for five minutes or five years'.

Amongst the participants there emerged a distinct perception of a line of division between themselves and the RPOs, and between those RPOs who supported SCs, and those who did not. For example, one SC recalled:

'I remember being crewed with a woman who probably didn't want me to be there.... There was a very unsubtle radio conversation she had with her colleague... Basically said, 'are you all right with that Special? ... Ok if it looks like it's tense I'll come over and take over'. I'm like 'guys, I'm sat right here... I wasn't born yesterday and I can handle myself... I've felt particularly grubby and horrible about it afterwards.'

The SCs felt that some RPOs viewed them as the 'out-group' (Tajfel, 1979), both as individuals, and as a separate part of the organisational structure. This distinction was manifest in a RPO's behaviour towards a SC, who stated:

'I was on duty with a Regular who doesn't like Specials... you are there to do a job but I think it does help when you can at least have a conversation with the person you are spending up to eight hours with!'

The SCs linked this experience to adverse feelings in self-esteem and increased stress (Meister, 2014):

'It's just feeling that... made to feel inferior, when you don't feel confident in your own ability... you want to be a useful resource to someone'.

Despite the adverse effect that being made to feel inadequate can have, the SCs seemed to acknowledge and understand the reasons that certain RPOs may feel this way towards them: 'Sometimes it can... make an officer uneasy being paired up with a Special because they don't know your experience... it must be quite unsettling...' 
The SCs were empathetic towards the RPOs, demonstrating shared empathic personality traits (Skitka et al., 2016), and an awareness of how, despite the differences in training and experience (the SCs train for eight weekends, the RPOs for 36 weeks), both SCs and RPOs have the same roles and legal powers:

'I do believe the training for Specials is diabolical... Regulars think 'hang on these Specials are coming through really poorly trained and they going to make me 10 times the amount of paper work...'

Because of this the SCs believed that they must work extra hard to 'prove themselves' to the RPOs in order to be accepted and recognised:

'We would all get painted with the same brus ... we have had substandard training, but we are willing and we are able if you give us the opportunity we will prove us right...'

Subtheme 2: The impact of acceptance by the RPOS

Group affiliation and acceptance is considered important to individual's perception of their selfworth (Tajfel, 1979). Once a SC has overcome the RPOs' apprehension a new, highly positive and equitable relationship develops:

'I will say what you will get is as soon as you break that barrier that you aren't a seat warmer, ...you are welcomed with open arms onto the shift... they will absolutely support you and do anything and treat you like a paid officer'.

\section{Theme 3: Levels of training}

Some of the lack of self-confidence discussed by the participants can be explained by their views on training. Lack of training was viewed by the SCs as a barrier to fulfilling their potential, and provided an explanation for the lack of support from some RPOs:

'...it's definitely hard to know when you should be taking an active role and when you should refer to your much more experienced colleagues... they are trying to put you in to situations too early'. 
Subtheme 1: The relationship between training and action

It emerged that the lack of training could affect the safety of the SCs causing anxiety and a lack of confidence particularly in threatening situations that they may encounter (Qi et al., 2018). One SC stated:

'You basically do one weekend being trained to use your baton... there is no structured or formal way to practice that. I am very conscious that its almost two years till my next training day for that and if I end up having to draw a baton in 22 months' time it will be the first time I have done it in 22 months... The Regulars are wary of working with Specials because a lot of them have had bad experiences... A lady who I work with pointed out that a Special who had worked with her in the past, didn't help out while she was being kicked on the floor and that makes her wary of working with someone until she has had some sort of positive experience with them, which is very understandable.'

Subtheme 2: Procedural barriers to improving skills

Many of the SCs stated that they were keen to undertake further training but that access to appropriate courses was unavailable or difficult to obtain. For SCs this was a source of frustration and anxiety, with an adverse effect on their mental health (Colley, 2012), as well as holding back their development:

'I can't get on the course to do... driving in a police car. I can still drive them but I have to get a sergeant to sign my pocket book to specifically authorise me... it feels a bit demeaning sometimes...'

\section{'Mind the gap!'}

When reflecting on the reasons for the lack of training, many participants thought that financial resources were the main source of the problem. SCs consider themselves to be a critical resource to support the Police to work effectively: 
'When you talk about why you can never get a helicopter to turn up to a job, there's never a dog to turn up to a job, there's not enough devices to go round, there's not enough training, everything eventually will bend back to budget cuts, everything'.

\section{Subtheme 1: Filling the gap}

SCs were acutely aware of the implications of financial restrictions and limitations on resources and working conditions:

'It only takes one person to be off sick and they can't seem to get the cover for them because they can't afford the overtime... they just feel like they are chronically understaffed compared to the position even like five years ago... a full shift complement was considered to be, two sergeants, fourteen officers and Specials were add-ons. Now the average shift is one sergeant and eight staff including Specials...'

\section{Subtheme 2: Intangible value}

The SCs expressed satisfaction from supporting the Police during the times of financial cuts and felt valued for their contribution:

'I also know those 30 or 40 hours make a real difference whether that just by supporting my Regular colleagues so one of them isn't going out singled crewed...'

Although austerity measures in Public Services has been shown to ultimately increase emotional suffering in the workforce and can lead to increased difficulties in the individual being able to carry out their role (Colley, 2012), austerity may have positive consequences for the Special Constables. With lower numbers of RPOs the SCs gained more experience than they might have previously had:

'The more stricter the budgets have got and the fewer number of officers - the more of a difference we make... its sort of a better side-effect if one can be found.' 


\section{Discussion}

The main purpose of the study was to gain an understanding of how current SCs viewed their role, to understand their experiences, and to examine how best to encourage optimal future participation in this voluntary role. Interviews with the participants provided insight through the identification of four overarching themes: 'Proud to be a Special', 'Lines of division', 'Levels of Training', and 'Mind the Gap'.

It was apparent that the SCs' volunteering was directed less on an organisational level towards the Justice System or the Police Force, but on the more individualistic and 'grass roots' level of the RPOs. So, although the SCs volunteer and represent a necessary and welcome asset (Hamlyn et al., 2015) for the Police, it is the RPOs with whom the SCs work whose welfare was the focus of the volunteering effort. In conjunction, it was with the RPOs that the SCs aspired to share characteristics, experience, goals and values (Abrams and Hogg, 1988; Taylor and Hanna, 2017) This could be attributed to the future aspirations of some of the SCs in becoming RPOs. Accordingly, volunteering as a SC fulfilled egoistic, altruistic purposes, and collectivism (Batson, 1994; Fitch, 1987; Tajfel, 1979) but lacked the principalism as a potential motivator. In addition, these current SCs did not focus on the status, power or right to wear a uniform that had previously been presented as a motivation to volunteer (Gaston and Alexander, 2001). The SCs' perceptions of being undervalued and unrecognised for their contribution (Mirrlees-Black and Byron, 1994) by the RPOs was still prevalent, though the SCs demonstrated understanding of the reasons for this and took responsibility to address the issue through the quality of their work. Accordingly, to promote recruitment and decrease attrition it may be advantageous to focus on the benefit of SCs to the RPOs rather than to centre the SC role within the wider contexts of the Police Force or Criminal Justice System.

The impact of austerity had both positive and negative impacts on the SCs with frustration expressed about the lack of training and development of skills but conversely, in contrast to 
previous research (Millie, 2016), the unexpected positive consequence of enabling higher levels of experience. Higher levels of experience have the additional advantage of potentially improving the relationship between the SCs and the RPOs as the SCs have greater opportunity to put their skills into practice and demonstrate their competency. Greater experience also affords the SCs the opportunity to obtain the respect and confidence of the RPOs, and thus to promote the unique person-environment fit that is supportive of positive volunteering experience (Maki and Snyder, 2017). This suggests that the role of a SC may, rather controversially, be supported by a limit on the number of SCs recruited, and that attrition in the short-term could be welcomed to enable a more positive balance between providing a crucial resource (Nesbit and Brudney, 2010), who are adequately trained, and providing sufficiently high levels of demand to enable positive levels of experience. In an era of austerity, a reduced, but more active cohort of SCs would be supportive of value for money (Whittle, 2014), and positive engagement. That said, the current changes proposed by Higgins (2018) have resulted in the concentration of SCs duties solely on Neighbourhood Policing, which have the potential to segregate the SCs and RPOs even further. Furthermore, there is a possibility that inadequate levels of training and the reduction in opportunities for the RPOs to support the SCs and potentially decrease the number of volunteers willing to apply for, or continue in the role of SC.

The current study recognises the limitations with the small sample size of the participants. However, the themes elicited through the interview analyses resonated in all the participant interviews. To improve the generalisability of the findings, it is planned to conduct a further study with SCs from a wider geographical area and to triangulate through the inclusion of interviews with RPOs and members of the public also.

In conclusion, the role of SCS can, with experience, be supportive of facilitating law enforcement in England and Wales. SCs are well aware that they provide a financially utilitarian role, but this is viewed merely as an adjunct as their focus is towards gaining the respect and 
approval of the RPOs with whom they work rather than on an organisational or governmental level. A reduction in the number of SCs may be supportive in improving skills and experience, would be more cost effective in reducing attrition, and promote better working relationships between SCs and Regular Police Officers.

\section{References}

Abrams D and Hogg MA (1988) Social Identifications: A social psychology of intergroup relations and group processes. Florence: Routledge.

Akintola O (2011) What motivates people to volunteer? The case of volunteer AIDS caregivers in faith-based organizations in KwaZulu-natal, South Africa. Health Policy and Planning 26: 53-

\section{2. https://doi.org/10.1093/heapol/czq019}

Batson CD (1981) Is empathic emotion a source of altruistic motivation? Journal of Personality and Social Psychology 40: 290-302. https://doi:10.1037/0022-3514.40.2.290

Batson CD (1994) Why act for the public good? Four answers. Personality and Social Psychology Bulletin 20: 603-610. https://doi.org/10.1177/0146167294205016

Batson CD (2011) Altruism in humans. New York: Oxford University Press.

Braun V and Clarke V (2006) Using thematic analysis in psychology. Qualitative Research in Psychology 3: 77-101. https//doi:10.1191/1478088706qp063oa

Braun V and Clarke V (2013) Successful qualitative research. Los Angeles: Sage.

Braun V, Clarke V and Terry G (2012) Thematic analysis. APA Handbook of Research Methods in Psychology 2: 57-71. https://doi.org/10.1037/13620-004

Braun V and Clarke V (2013) Successful qualitative research. Los Angeles: Sage.

Bullock K (2017) Shoring up the 'home guard'? Reflections on the development and deployment of police support volunteer programmes in England and Wales. Policing and Society, 27, 341357. doi:10.1080/10439463.2015.1058378 
Bullock K and Leeney D (2016). On matters of balance: An examination of the deployment, motivation and management of the special constabulary. Policing and Society: An International Journal of Research and Policy, 26, 483-502. doi:10.1080/10439463.2014.949713

Bullock K and Millie A (Eds.) (2018) The Special Constabulary: Historical Context, International Comparisons and Contemporary Themes. London: Routledge.

Casselden B, Pickard A, Walton G and McLeod J (2017) Keeping the doors open in an age of austerity? Qualitative analysis of stakeholder views on volunteers in public libraries. Journal of Librarianship and Information Science, 47, 187-203. doi:10.1177/0961000617743087 College of Policing (2017a). FAQs (powers, time commitment, training, promotion). Available at: http://recruit.college.police.uk/Special/Pages/faqs.aspx

College of Policing (2017b). Initial Learning. Available at: www.college.police.uk/What-wedo/Learning/Curriculum/Initial-learning/Pages/Initial-learning.aspx

Colley H (2012) Not learning in the workplace: Austerity and the shattering of illusion in public service work. Journal of Workplace Learning 24: 317-337.

https://doi.org/10.1108/13665621211239868

Cook TJ and Scioli FP (1974) Public participation in the criminal justice system: Volunteers in police, courts, and correctional agencies. Policy Studies Journal 3: 44-48.

https://doi.org/10.1111/j.1541-0072.1974.tb01126.x

Creswell JW (2013) Qualitative inquiry and research design. Los Angeles: Sage.

Disney R and Simpson P (2017) Police workforce and funding in England and Wales. Available at: https://www.ifs.org.uk/uploads/publications/bns/bn208.pdf (accessed 20 September 2018). Dobrin A (2017) Volunteer police: History, benefits, costs and current descriptions. Security Journal, 30, 717-733. doi:10.1057/sj.2015.18 
Dobrin A and Wolf R (2016) What is known and not known about volunteer policing in the United States. International Journal of Police Science and Management, 18, 220-227. doi:10.1177/1461355716660732

Fishbach A, Henderson MD and Koo M (2011) Pursuing goals with others: Group identification and motivation resulting from things done versus things left undone. Journal of Experimental Psychology: General 140: 520-534. http://dx.doi.org/10.1037/a0023907

Fitch RT (1987) Characteristics and motivations of college students volunteering for community service. Journal of College Student Personnel 28: 424-431.

Garbarino S, Cuomo G, Chiorri C and Magnavita N (2013) Association of work-related stress with mental health problems in a special police force unit. BMJ Open, 3(7)10.1136/bmjopen-2013002791. Available at: http://bmjopen.bmj.com/content/3/7/e002791.abstract (accessed 20 September 2018).

Gaston K and Alexander JA (2001) Effective organisation and management of public sector volunteer workers: Police special constables. International Journal of Public Sector Management 14: 5974. https://doi.org/10.1108/09513550110387075

Gaines L and Kappeler V (2011) Policing in America, $7^{\text {th }}$ edition. London: Elsevier.

Gorden DW (1988) Organizational citizenship behavior: The good soldier syndrome. Lexington, MA: Lexington Books.

Hamlyn B, Fitzpatrick A, Coleman E and Bolling K (2015) Giving of time and money - findings from the 2012-13 community life survey. Available at:

https://www.gov.uk/government/uploads/system/uploads/attachment_data/file/314432/20 12-2013-giving-time-and-money-report.pdf (accessed 20 September 2018). Henderson K (1980) Programming volunteerism for happier volunteers. Parks and Recreation 15: 6164.

Hewson A (2013) What can I do? Available at: 


\section{http://www.prisonreformtrust.org.uk/portals/0/documents/what\%20can\%20i\%20do.pdf}

Higgins A (2018) The future of neighbourhood policing \& nbsp. Available at: http://www.policefoundation.org.uk/2017/wp-content/uploads/2010/10/TPFJ6112-Neighbourhood-PolicingReport-WEB_2.pdf

Home Office statistical bulletin 11/18 police workforce, England and Wales, 31 March 2018. Available at: $\underline{\text { https://assets.publishing.service.gov.uk/.../uploads/.../hosb1118-police-workforce.pdf }}$ Jordan B (2012) Making sense of the 'Big Society': Social work and the moral order Journal of Social Work, 12, 630-646. doi:10.1177/1468017310394241.

Kochel T and Weisburd D (2019). The impact of hot spots policing on collective efficacy: Findings from a randomized field trial. Justice Quarterly, 36(5), 900-928.

Maki A and Snyder M (2017) Investigating similarities and differences between volunteer behaviors: Development of a volunteer interest typology. Non-profit and Voluntary Sector Quarterly 46:

\section{5-28. https://doi.org/10.1177/0899764015619703}

Meer J, Brown AL and Williams JF (2013) Why do people volunteer? An experimental analysis of preferences for time donations. National Bureau of Economic Research. 10.3386/w19066 Available at: http://www.nber.org/papers/w19066 (accessed 20 September 2018).

Meister A (2014) Feeling misidentified: The consequences of internal identity asymmetries for individuals at work. The Academy of Management Review 39: 488-512. https://doi.org/10.5465/amr.2013.0102

Millie A (2016) Volunteering within the police experiences of special constables and police support volunteers. Available at: https://repository.edgehill.ac.uk/8206/ (accessed 20 September 2018). Mirrlees-Black C and Byron C (1994) Special considerations: Issues for the management and organisation of the volunteer police. Available at: library.college.police.uk/docs/horpu/rup088.pdf (accessed 20 September 2018). 
Nesbit R and Brudney JL (2010) At your service? Volunteering and national service in 2020. Public Administration Review 70: S107-S113. https://doi.org/10.1111/j.1540-6210.2010.02252.x National Police Chiefs Council (NPCC) (2018). Policing vision 2025. Available at: https://www.npcc.police.uk/documents/Policing\%20Vision.pdf (accessed 20 December 2018).

O’Neill, M (2015) Police community support officers in England: A dramaturgical analysis. Policing and Society: An International Journal of Research and Policy, 27, 21-39.

doi:10.1080/10439463.2015.1020805

Pepper I (2014) Do part-time volunteer police officers aspire to be regular police officers? The Police Journal 87(2): 105-113. https://doi.org/10.1350/pojo.2014.87.2.667

Pepper IK and Wolf R (2015) Volunteering to serve: An international comparison of volunteer police officers in a UK north east police force and a US Florida sheriff's office. The Police Journal: Theory, Practice and Principles 88: 209-219. https://doi.org/10.1177/0032258X15585251 Police and Justice Act (2006) UK: Crown copyright.

Prouteau L and Sardinha B (2015) Volunteering and country-level religiosity: Evidence from the European Union. VOLUNTAS: International Journal of Voluntary and Nonprofit

Organizations 26: 242-266. https://doi.org/10.1007/s11266-013-9431-0

Pratt A (2019) Police stations: Are they a thing of the past? Available: https://commonslibrary.parliament.uk/home-affairs/crime/police-stations-are-they-a-thing-of-thepast/.

Qi S, Hassabis D, Sun J, Guo F, Daw N and Mobbs D (2018) How cognitive and reactive fear circuits optimize escape decisions in humans. Proceedings of the National Academy of Sciences 115:3186-3191. https://doi.org/10.1073/pnas.1712314115

Shye S (2010) The motivation to volunteer: A systemic quality of life theory. Social Indicators Research 98:183-200. https://doi.org/10.1007/s11205-009-9545-3 
Skitka LJ, Bauman CW and Mullen E (2016) Morality and justice. In: Sabbagh C and Schmitt M (eds) Handbook of social justice theory and research. NY: Springer Science and Business Media, pp. 407-423.

Skoglund A (2006) Do not forget about your volunteers: A qualitative analysis of factors influencing volunteer turnover. Health and Social Work 31: 217-220. Available at:

http://nclc203wagner.pbworks.com/f/vol\%20turnover\%20qual.pdf (accessed 20 September 2018).

Sterling JW (1972) Changes in role concepts of police officers. Washington, DC: International Association of Chiefs of Police.

Strudwick K, Jameson J and Rowe J (2017). Developing volunteers in policing: assessing the potential volunteer police community police officer. Policing: A Journal of Policy and Practice, pax056. doi:10.1093/police/pax056

Tajfel H (1979) Individuals and groups in social psychology. British Journal of Social and Clinical Psychology 18: 183-190. https://doi.org/10.1111/j.2044-8260.1979.tb00324.x

Taylor LK and Hanna JR (2017) Altruism born of suffering among emerging adults in Northern Ireland. Journal of aggression, conflict and peace research 10: 157-169.

https://doi.org/10.1108/JACPR-01-2017-0271

Thomas E and Buck K (2010) Peer mentoring in a young offenders' institution. Widening Participation and Lifelong Learning 12: 67-73. https://doi.org/10.5456/WPLL.12.3.67

Van Steden R and Mehlbaum S (2018). Police volunteers in the Netherlands: a study on policy and practice. Policing and Society, 1-14. doi:10.1080/10439463.2018.1523165

Whittle J (2014) The rise of the special constabulary: Are forces getting value for money from their voluntary officers? An empirical study in Avon and Somerset Police. The Police Journal: Theory, Practice and Principles 87: 29-39. https://doi.org/10.1350/pojo.2014.87.1.649 


\author{
Wolf R, Pepper L and Dobrin A (2017). An exploratory international comparison of professional \\ confidence in volunteer policing. Police Journal: Theory, Practice and Principles, 90, 91-106. \\ doi:10.1177/0032258X16671966
}

